Journal of Animal and Veterinary Advances 10 (9): 1219-1226, 2011

ISSN: $1680-5593$

(C) Medwell Journals, 2011

\title{
Catch Efficiency of Monofilament Gill Nets Configured at Various Colors and Hanging Ratios
}

\author{
Bulent Orsay and Murside Dartay \\ Faculty of Fisheries, Firat University, 23119 Elazig, Turkey
}

\begin{abstract}
This study has been carried out between September 2004 and April 2006 at 8 different stations located within the fishing zone of the Keban Dam Lake Cemisgezek Fishery Cooperative (Elazig/Turkey). In order to identify the effect of colored gill nets in fish catching in the Keban Dam lake, nets of $40 \mathrm{~mm}$ mesh size were colored green, blue, burgundy and black and these 4 different colored, same mesh size nets were equipped with 0.50 and 0.67 hanging ratios, totaling up to 8 nets of different configurations. During the 2 years research, a total of 1169 fish were caught, 606 of which were caught in the monofilament gill nets with 0.50 hanging ratio and the remaining 563 caught in the monofilament gill nets with 0.67 hanging ratio. The fish caught in the nets were classified according to the hanging ratio, mesh size and the color of the nets. Then the total sizes of the fish were measured and they were weighed; lastly, the mean fish length and weight as well as the standard deviation from these mean values were calculated and recorded. The statistical relation between the fish populations caught with nets possessing differing mesh size, color and hanging ratio properties were compared using the $\chi^{2}$-test. The material color of the gill nets was found to be effective on the catch efficiency. Barbus rajanorum mystaceus and Capoeta trutta (Cyprinidae)were caught in black and green nets with $0.40 \mathrm{~mm}$ mesh size and 0.50 hanging ratio while mostly B. esocinus and B. xanthopterus (Cyprinidae) were caught in the blue nets with the same mesh size and 0.67 hanging ratio. In conclusion, it is determined that black gill nets can be used for Capoeta trutta, burgundy for carp, green for Barbus rajanorum mystaceus and blue for barbell in Keban Dam lake in Cemisgezek district.
\end{abstract}

Key words: Keban dam lake, colored gill nets, hanging ratio, black gill nets, Turkey

\section{INTRODUCTION}

Economically feasible management of fishery resources and ensuring the continuity of the present live stocks requires above all conscious and technically adequate fishing. The way how the stocks would be preserved provides the basis for the fishing technology. There are many different aspects of fisheries management that affect the fisheries directly or indirectly. The aim is to acquire the maximum product per unit area and to procure its maintenance. In order to be able to realize this goal, it is imperative to have knowledge on the fish stocks and how much of these stocks to catch by which technique. It is for certain that catching by using inappropriate fishing gears will damage the fish stocks.

Gill nets with varying properties are used in catching fish that are of various body structures and sizes and that live in inner waters. The catch efficiencies of these gill nets are very different depending on the various types of fish. For this reason, it is of crucial importance for the fisheries management to know the effects of varying types of fishing gear on differing types of fish. It is a widely accepted fact to regard the unit catch force in the lakes as an indicator of the fish stocks (Ricker, 1975; Prouzed and Dumas, 1988; Pawson, 1991; Acosta and Appeldoorn, 1995).

Fishing by gill nets is a widely acknowledged type of catching throughout the world. These nets possess the advantage of both having low costs and providing simple catch applications. Besides, gill nets are amongst the most suitable fishing gear for catching fish in rocky regions without damaging the means of catch where it is impossible to do so by using other means of active fishing gear; trawl nets and sweeping nets (Hamley, 1975; Laevastu and Favorite, 1988; Engas and Lokkeborg, 1994; Kurkilathi and Rask, 1996).

It has been previously reported that the structure, the material, the mesh size, the netting twine thickness, the netting twine color and the hanging ratio of the nets that are going to be used in fishing are influential on the catch efficiency (Hamley, 1980; Millner, 1985). Light is one of the main environmental factors affecting the visual attributions of fish (Dickson, 1989). Besides light, the properties of the object or the organism to be seen

Corresponding Author: Murside Dartay, Faculty of Fisheries, Firat University, 23119 Elazig, Turkey 
are also important in the process of vision. The color, the thickness and the size of the object may cause the fish to det ect, perceive and be attracted by the object and as a result to respond to the object (Holst et al., 2002). Gill nets are critically important in fisheries management of target species for the purpose of the assessment of fish stocks in biological research.

The best way to benefit from the fish stocks is to catch them without endangering their future and by letting them renew themselves. The determination of a safe footing for fishing is only possible through the provision of the stock management (Hamley, 1975). However, many types of fish in various regions are of varying age, size and weight. Due to this reason, the catch is usually of mixed type allowing the unwanted and endangered species also to be caught along with the target species. Following the completion of the Keban Dam, the $687 \mathrm{~km}^{2}$ dam lake has been a food source for Elazig and other cities in the region owing to the types and the amount of fish it harbors. It is without doubt that the fish caught from the lake assists in supplying for the deficiency in the amount of protein acquired from animal sources. The production and consumption of fish products in the country displays differences amongst the regions being high in the coastal regions and low in the inland regions, especially in the central parts of East Anatolian region.

In this study the aim was to investigate the fish species that are being economically caught in the Keban Dam lake Cemisgezek region in terms of their sensitivity to different colors as well as their concentration in different colored nets and to detect which color and hanging ratio is more efficient in terms of different species.

\section{MATERIALS AND METHODS}

This study has been conducted between September 2004 and April 2006 in the Keban Dam lake Cemisgezek region (Elazig/Turkey) (Fig. 1). During the research which lasted for two fishing seasons, monofilament gill nets of mesh size $40 \mathrm{~mm}$ have been dyed in green, blue, burgundy and black using fabric dyes and have been made ready for investigation. Two packs of each of the monofilament gill nets of mesh size $40 \mathrm{~mm}$ are bought. The nets were then cut in half along its length (200 meshes/2) and each of the nets with the following mesh sizes were dyed
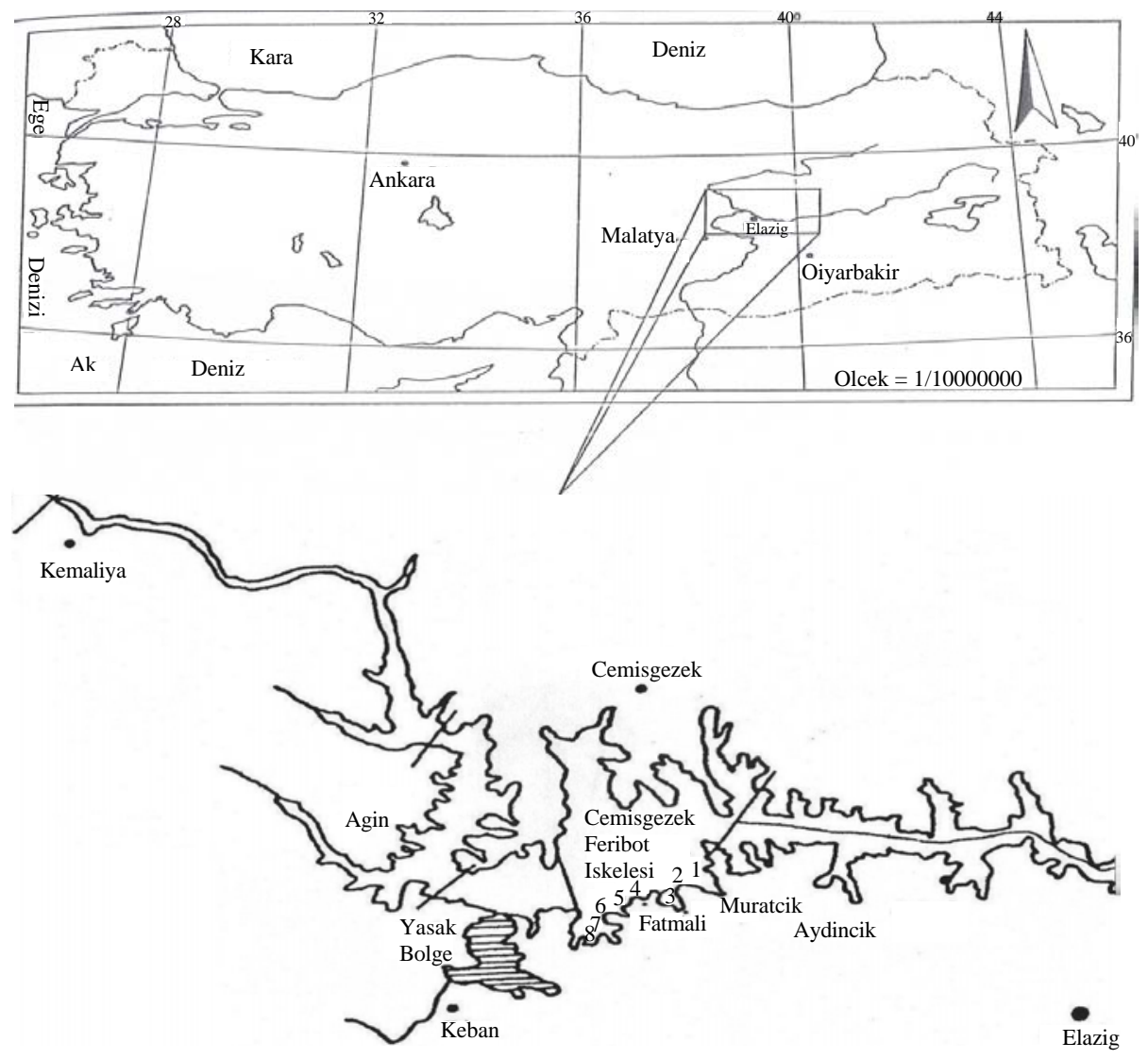

Fig. 1: The research area and the study stations 
in green, blue, burgundy and black. Four colored nets of each mesh size were adorned with 0.50 and 0.67 hanging ratios and a total of 8 nets were ready to be used.

The 8 nets with the given specifications above were randomly added one after the other and were cast (spread) at approximately 18:00 in the fishing areas. The nets were collected at 6:00 in the morning. This way, it was secured for the nets to reside in water for $12 \mathrm{~h}$. The caught fish were collected from the nets that have been taken out of the water onto the boat. The casting and the collection of the nets were achieved solely on human power without the assistance of any equipment.

The study stations were distributed randomly along the research area since fish of various sizes may inhabit different regions. The fish were caught at depths of 2-20 m. Fish were collected in different cases following the collection of the nets. The number of fish collected from each net was recorded and their sizes were measured on the measurement board up to $0.1 \mathrm{~cm}$ accuracy with mouth closed from the tip of the nose up to the longest tail fin as described by Lagler (1978).

The total weights were recorded in an electronic balance up to $0.1 \mathrm{~g}$ accuracy and were recorded in readily prepared forms. The length and the weight of the fish caught in the nets were then recorded in Microsoft Excel in categories depending on the hanging ratios, mesh sizes and colors of the nets. The averages, the standard deviations and the standard errors were calculated.
The comparison of the fish that were caught in nets with differing mesh sizes, colors and hanging ratios were carried out using the chi-square multiple testing in Microsoft Excel (version Microsoft Office, 2000).

\section{RESULTS AND DISCUSSION}

A total of 1169 fish, 606 in the monofilament gill nets with 0.50 hanging ratio and 563 fish in the gill nets with 0.67 hanging ratio were caught during the research (Table 1). All fish species and the sub-species that are under investigation are from the Cyprinidae family. These are Cyprinus carpio, Barbus esocinus and Barbus xanthopterus, Capoeta trutta and Barbus rajanorum mystaceus (Cyprinidae).

All the acquired data have been taken into consideration separately in terms of the response to hanging ratios, mesh sizes and the color of the gill nets. The distribution of the number and the percentage of the fish among the different colored gill nets with a 0.50 hanging ratio and a $40 \mathrm{~mm}$ mesh size in the study conducted in Keban Dam lake Cemisgezek region are shown in Table 2. A total of 331 fish have been caught in the monofilament gill nets with a 0.50 hanging ratio and a $40 \mathrm{~mm}$ mesh size. The distribution of this population with respect to the net color and the type of the caught species are shown in Fig. 2. The $\chi^{2}$ table of the colored gill nets with 0.50 hanging ratio and a mesh size of $40 \mathrm{~mm}$ is

Table 1: The number (n) and the percentage (\%) of fish caught in different colored gill nets with mesh size $40 \mathrm{~mm}$ and with the hanging ratios of 0.50 and 0.67

\begin{tabular}{|c|c|c|c|c|c|c|c|c|c|c|c|c|c|c|c|c|}
\hline \multirow[b]{4}{*}{ Species } & \multicolumn{16}{|c|}{ The $40 \mathrm{~mm}$ mesh size } \\
\hline & \multicolumn{8}{|c|}{0.50 hanging ratio } & \multicolumn{8}{|c|}{0.67 hanging ratio } \\
\hline & \multicolumn{2}{|c|}{ Green } & \multicolumn{2}{|c|}{ Blue } & \multicolumn{2}{|c|}{ Burgundy } & \multicolumn{2}{|c|}{ Black } & \multicolumn{2}{|c|}{ Green } & \multicolumn{2}{|c|}{ Blue } & \multicolumn{2}{|c|}{ Burgundy } & \multicolumn{2}{|c|}{ Black } \\
\hline & $\mathrm{n}$ & $\%$ & $\mathrm{n}$ & $\%$ & $\mathrm{n}$ & $\%$ & $\mathrm{n}$ & $\%$ & $\mathrm{n}$ & $\%$ & $\mathrm{n}$ & $\%$ & $\mathrm{n}$ & $\%$ & $\mathrm{n}$ & $\%$ \\
\hline C. trutta & 32 & 5.28 & 28 & 4.62 & 21 & 3.47 & 80 & 13.20 & 58 & 10.30 & 39 & 6.92 & 7 & 1.24 & 74 & 13.14 \\
\hline C. corpio & 8 & 1.32 & 5 & 0.83 & 16 & 2.64 & 6 & 0.99 & 5 & 0.88 & 6 & 1.06 & 9 & 1.59 & 7 & 1.24 \\
\hline $\begin{array}{l}\text { B. rajanorum } \\
\text { mystaceus }\end{array}$ & 41 & 6.77 & 32 & 5.28 & 17 & 2.80 & 19 & 3.14 & 49 & 8.08 & 7 & 1.24 & 16 & 2.40 & 32 & 5.68 \\
\hline $\begin{array}{l}\text { B. esocinus and } \\
\text { B.xanthopterus }\end{array}$ & 6 & 0.99 & 8 & 1.32 & 7 & 1.16 & 5 & 0.83 & 7 & 1.24 & 8 & 1.42 & 6 & 1.06 & 9 & 1.59 \\
\hline Total & 87 & 14.36 & 73 & 12.05 & 61 & 10.07 & 110 & 18.15 & 119 & 21.13 & 60 & 10.60 & 38 & 6.47 & 122 & 21.66 \\
\hline
\end{tabular}

Table 2: The distribution of the number (n) and the percentage (\%) of the fish among the different colored gill nets with a 0.50 hanging ratio and a $40 \mathrm{~mm}$ mesh size

\begin{tabular}{|c|c|c|c|c|c|c|c|c|}
\hline \multirow[b]{2}{*}{ Species } & \multicolumn{2}{|c|}{ Green } & \multicolumn{2}{|c|}{ Blue } & \multicolumn{2}{|c|}{ Burgundy } & \multicolumn{2}{|c|}{ Black } \\
\hline & $\mathrm{n}$ & $\%$ & $\mathrm{n}$ & $\%$ & $\mathrm{n}$ & $\%$ & $\mathrm{n}$ & $\%$ \\
\hline C. trutta & 32 & 9.67 & 28 & 8.46 & 21 & 6.34 & 80 & $\overline{24.17}$ \\
\hline C. carpio & 8 & 2.42 & 5 & 1.51 & 16 & 4.83 & 6 & 1.81 \\
\hline B. rajanorum mystaceus & 41 & 12.39 & 29 & 8.76 & 17 & 5.14 & 19 & 5.74 \\
\hline B. esocinus and B. xanthopterus & 7 & 2.12 & 11 & 3.32 & 6 & 1.81 & 5 & 1.51 \\
\hline Total & 88 & 26.60 & 73 & 22.05 & 60 & 18.12 & 110 & 33.23 \\
\hline
\end{tabular}


Table 3: The chi-square distribution table of the fish distribution amongst the different colored gill nets with 0.50 hanging ratio and a mesh

\begin{tabular}{lccccrrrr}
\hline size of $40 \mathrm{~mm}$ & $\begin{array}{c}\text { Observed } \\
\text { no of fish }\end{array}$ & $\begin{array}{c}\text { Expected } \\
\text { no of fish }\end{array}$ & $\begin{array}{c}\text { Observed } \\
\text { no of fish }\end{array}$ & $\begin{array}{c}\text { Expected } \\
\text { no of fish }\end{array}$ & $\begin{array}{r}\text { Observed } \\
\text { no of fish }\end{array}$ & $\begin{array}{r}\text { Expected } \\
\text { no of fish }\end{array}$ & $\begin{array}{r}\text { Observed } \\
\text { no of fish }\end{array}$ & $\begin{array}{r}\text { Expected } \\
\text { no of fish }\end{array}$ \\
Species & 32 & 41 & 28 & 34 & 21 & 29 & 80 & 52 \\
C. trutta & 8 & 9 & 5 & 8 & 16 & 7 & 6 & 12 \\
C. carpio & 41 & 30 & 29 & 25 & 17 & 21 & 19 & 37 \\
B. rajanorum mystaceus & 7 & 7 & 11 & 6 & 6 & 5 & 5 & 9 \\
B. esacinus and B. Xanthopterus & 88 & 87 & 73 & 73 & 60 & 62 & 110 & 110 \\
Total & & & & &
\end{tabular}

Table 4: The distribution of the number (n) and the percentage (\%) of the fish among the different colored gill nets with a 0.67 hanging ratio and a $40 \mathrm{~mm}$ mesh size

\begin{tabular}{|c|c|c|c|c|c|c|c|c|}
\hline \multirow[b]{2}{*}{ Species } & \multicolumn{2}{|c|}{ Green } & \multicolumn{2}{|c|}{ Blue } & \multicolumn{2}{|c|}{ Burgundy } & \multicolumn{2}{|c|}{ Black } \\
\hline & $\mathrm{n}$ & $\%$ & $\mathrm{n}$ & $\%$ & $\mathrm{n}$ & $\%$ & $\mathrm{n}$ & $\%$ \\
\hline C. trutta & 58 & 17.11 & 39 & 11.51 & 7 & 2.06 & 74 & 21.83 \\
\hline C. corpio & 5 & 1.48 & 6 & 1.77 & 9 & 2.06 & 7 & 2.06 \\
\hline $\begin{array}{l}\text { B. rajanorum } \\
\text { mystaceus }\end{array}$ & 49 & 14.45 & 7 & 2.06 & 16 & 4.72 & 32 & 9.44 \\
\hline $\begin{array}{l}\text { B. esocinus and } \\
\text { B. xonthopterus }\end{array}$ & 7 & 2.06 & 8 & 2.36 & 6 & 1.77 & 9 & 2.66 \\
\hline Total & 119 & 35.10 & 60 & 17.70 & 38 & 11.21 & 122 & 35.99 \\
\hline
\end{tabular}

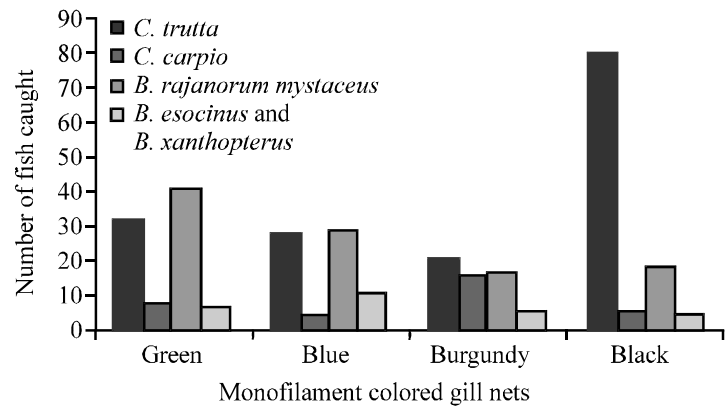

Fig. 2: The number of fish caught in the colored gill nets with 0.50 hanging ratio and a mesh size of $40 \mathrm{~mm}$

shown in Table 3. The difference in the amount of expected and observed fish in response to different net colors in Table 3 was found to be statistically significant $\left(\chi^{2}=55.02, \mathrm{~F}=9, \mathrm{p}<0.05\right)$.

Among the caught fish, the total length of C. trutta was observed to be in the range of $31.6-40.7 \mathrm{~cm}$ and its weight between 278 and $691 \mathrm{~g}$. The total length of C. carpio varied between 28.6 and $31.9 \mathrm{~cm}$ while its weight was in a range of $304-467$ g. B. rajanorum mystaceus had a total length varying between 34.9 and $46.9 \mathrm{~cm}$ and the weights varied between 368 and $505 \mathrm{~g}$. For $B$. esocinus and $B$. xanthopterus, the size range was $38.5-43.3 \mathrm{~cm}$ and the weight range was $496-804 \mathrm{~g}$.

A total number of 339 fish were caught in the Keban Dam lake Cemisgezek region in the nets with a hanging ratio of 0.67 and a mesh size of $40 \mathrm{~mm}$. The distribution of the numbers and the percentages of these fish among different colored nets are shown in Table 4. The population of 331 fish which have been caught in the monofilament gill nets with a 0.67 hanging ratio and a $40 \mathrm{~mm}$ mesh size are distributed as follows with respect

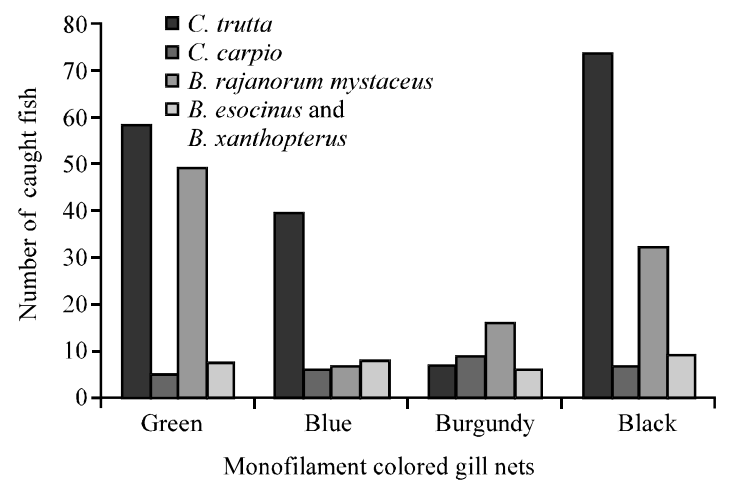

Fig. 3: The number of fish caught in the colored gill nets with 0.67 hanging ratio and a mesh size of $40 \mathrm{~mm}$

to the net color and the type of the caught species (Fig. 3). An investigation of the number of fish that has been caught in different colored nets in Fig. 3, mostly C. trutta has been caught in the green gill nets (58 fish) whereas C. carpio was caught the least (5 fish). Mostly C. trutta was caught in the blue gill nets (39 fish) and again $C$. carpio were caught the least ( 6 fish) in the blue gill nets as it was the case for the green gill nets.

The burgundy nets were useful in catching mostly B. rajanorum mystaceus (16 fish) and Barbus esocinus and Barbus xanthopterus were caught the least ( 6 fish). As it was the case for the blue and the green gill nets, mostly C. trutta was caught in the black gill nets ( 74 fish) and C. carpio were caught the least ( 7 fish). The $\chi^{2}$ table of the colored gill nets with a 0.67 hanging ratio and a mesh size of $40 \mathrm{~mm}$ is shown in Table 5.

The difference in the amount of expected and observed fish in response to different net colors in Table 5 was found to be statistically significant $\left(\chi^{2}=49.87, \mathrm{~F}=9, \mathrm{p}<0.05\right)$. Among the caught fish, the total length of C. trutta was observed to be in the range of $28.2-41.2 \mathrm{~cm}$ and its weight between 226 and $664 \mathrm{~g}$. The total length of $C$. carpio varied between 28.2 and $31.9 \mathrm{~cm}$ while its weight was in a range of $313-516 \mathrm{~g}$.

$B$. rajanorum mystaceus had a total length varying between 33.8 and $44.4 \mathrm{~cm}$ and the weights varied between 481 and $672 \mathrm{~g}$. For B. esocinus and B. xanthopterus, the size range was $33.6-39.2 \mathrm{~cm}$ and the weight range was $389-616 \mathrm{~g}$. In this study conducted in the Keban Dam 
J. Anim. Vet. Adv., 10 (9): 1219-1226, 2011

Table 5: The Chi-square distribution table of the fish distribution amongst the different colored gill nets with a 0.67 hanging ratio and a mesh size of $40 \mathrm{~mm}$

\begin{tabular}{|c|c|c|c|c|c|c|c|c|}
\hline \multirow[b]{2}{*}{ Species } & \multicolumn{2}{|l|}{ Green } & \multicolumn{2}{|l|}{ Blue } & \multicolumn{2}{|l|}{ Burgundy } & \multicolumn{2}{|l|}{ Black } \\
\hline & $\begin{array}{l}\text { Observed } \\
\text { no of fish }\end{array}$ & $\begin{array}{l}\text { Expected } \\
\text { no of fish }\end{array}$ & $\begin{array}{l}\text { Observed } \\
\text { no of fish }\end{array}$ & $\begin{array}{l}\text { Expected } \\
\text { no of fish }\end{array}$ & $\begin{array}{l}\text { Observed } \\
\text { no of fish }\end{array}$ & $\begin{array}{l}\text { Expected } \\
\text { no of fish }\end{array}$ & $\begin{array}{l}\text { Observed } \\
\text { no of fish }\end{array}$ & $\begin{array}{l}\text { Expected } \\
\text { no of fish }\end{array}$ \\
\hline C. trutta & 58 & 68 & 39 & 34 & 7 & 20 & 74 & 63 \\
\hline C. carpio & 5 & 3 & 6 & 5 & 9 & 3 & 7 & 10 \\
\hline B. rajanorum mystaceus & 49 & 41 & 7 & 16 & 16 & 12 & 32 & 37 \\
\hline B. esocinus and B. xanthopterus & 7 & 4 & 8 & 2 & 6 & 3 & 9 & 11 \\
\hline Total & 119 & 116 & 60 & 57 & 38 & 38 & 122 & 121 \\
\hline
\end{tabular}

lake Cemisgezek region, 2 different hanging ratios; 0.50 and 067 were used. The amount of caught fish with respect to the mesh size, the hanging ratios and the net color has been comparatively investigated using the $\chi^{2}$-test. In this research, in accordance with the general characteristics of Cyprinids, the fish activity was observed to increase with increasing temperature and hence the amount of fish caught in fall, winter and spring were different from each other.

The highest catch efficiency with the colored monofilament gill nets with a hanging ratio 0.50 and a mesh size of $40 \mathrm{~mm}$ was detected in the spring and the lowest efficiency was in winter. Investigation of the seasonal changes in the catch efficiency of the fish caught in monofilament gill nets with a hanging ratio of 0.50 and a mesh size of $40 \mathrm{~mm}$, the most efficient net in spring was found as the black net ( 67 fish, 20.24\%) and the least efficient was the burgundy net (41 fish, 12.38\%). Similarly in fall, the most efficient catch was made in black nets (26 fish, 7.85\%) and the least efficient catch was in the burgundy nets ( 12 fish, $3.62 \%$ ). During the winter, the most efficient net was the black gill net (18 fish, 5.43\%) as it was the case for the spring and the fall, however, the least efficient net was the green gill net ( 5 fish, $4.53 \%$ ).

The highest catch efficiency with the colored monofilament gill nets with a hanging ratio 0.67 and a mesh size of $40 \mathrm{~mm}$ was detected in the spring and the lowest efficiency was in winter. Investigation of the seasonal changes in the catch efficiency of the fish caught in monofilament gill nets with a hanging ratio of 0.67 and a mesh size of $40 \mathrm{~mm}$, the most efficient net in spring was found as the black net ( 79 fish, 23.29\%) and the least efficient was the burgundy net (19 fish, 5.59\%). In fall, the most efficient catch was made in green nets (40 fish, 11.79\%) and the least efficient catch was in the burgundy nets (11 fish, 3.23\%). During the winter, the most efficient net was the green gill net (25 fish, $7.38 \%$ ) and the least efficient net was the blue gill net ( 6 fish, $1.77 \%$ ). Catching fish by using unsuitable fishing gear ensures without doubt to harm the fish stocks. The catch force as well as the technical specifications of the fishing gear should be suitable for the stock. Over-practiced catch force would cause depletion in the stocks while not using the catch force enough would result in the inefficient utilization of the stock resources. The effectiveness of the catch force (the fishing boat and the number of fishermen, the number of nets or their length) is calculated from the amount of fish caught per unit catch force. The catch efficiencies of fishing gears are dependent upon the type of fish that is aimed to be caught. For this reason, the information on how different fishing gears affect the different types of fish is a crucial knowledge in fisheries management (Ricker, 1975; Prouzed and Dumas, 1988; Pawson, 1991; Balik and Cubuk, 2001).

During a catch operation, non-targeted species are also caught, sometimes in not so inconsiderable amounts, together with the desired species. The fact that approximately $27 \%$ of the world's fish products comprise of undesired species that have been caught sets out the size of the problem clearly (Alverson et al., 1994).

It has been previously reported that in selective catching of target species, color selection would be suitable and hence decrease the amount of undesired catch (Steinberg, 1964; Antony, 1981; Cui et al., 1991; Wardle et al., 1991; Trunen, 1996). In this study that has lasted for two catch seasons, gill nets of 4 different colors; green, blue, burgundy and black with a $40 \mathrm{~mm}$ mesh size and with two different hanging ratios; 0.50 and 0.67 were used.

In the research using gill nets of 9 different colors (white, orange, yellow, brown, dark brown, light blue, navy, light green, khaki) in the United States, in the new Mexico lake, Jester (1973) reported that all colored nets were effective in catching different types of fish and that a statistically meaningful relation existed between the gill net color and the fish species. In the study using gill nets of 4 different colors (green, blue, burgundy, black), a statistically meaningful $(\mathrm{p}<0.05)$ relation was observed between the fish species caught and the color of the net that has been used to catch that fish. The sensitivity of different fish species for gill nets of different colors has been in accordance with the results obtained by Jester (1973). In the study, the most efficient net was identified to be colored in black and this was followed by the green, blue and burgundy nets for the gill nets of $40 \mathrm{~mm}$ mesh size and a hanging ratio of 0.50 . 
The most efficient net was identified to be colored in blue and this was followed by the black, green and burgundy nets for the gill nets of $40 \mathrm{~mm}$ mesh size and a hanging ratio of 0.67 . Steinberg and Bohl (1985) as well as Tweddle and Bodington (1988) reported in their studies that lighter colored nets were more effective than the darker colored nets. In this study conducted in the Keban Dam lake, the lighter colored gill net (blue) was found to be more effective in gill nets with a hanging ratio of 0.67 and a mesh size of $40 \mathrm{~mm}$. From this aspect, the conducted study is in accordance with the studies of Steinberg and Bohl (1985) and Tweddle and Bodington (1988).

Kara has reported that the darker nets were more effective than the lighter nets in the study conducted in the Mediterranean on Diplodus annularis. In this, study the darker colored gill net (black) was found to be more effective in monofilament gill nets with a hanging ratio of 0.50 and a mesh size of $40 \mathrm{~mm}$.

The catch performance of 8 different gill nets (red, black, white, blue, light green, khaki, yellow and brown) was evaluated on 4 different species in Beysehir lake and different colors were observed to aid in catching different types of fish. Another study in India reported white nets to be more effective than the yellow, green, brown and blue nets (Narayanappa et al., 1977). In that particular research, it has been reported that even the shade of the color affected the type of fish that was caught.

The color of the most efficient nets in terms of the total amount of fish caught in Beysehir lake in descending order is red, black, white, light green, yellow, blue, khaki, brown and specifically for Stizostedion lucioperca, the order is light green, yellow, white, red, black, blue and dark green (Balik and Cubuk, 2001).

Several researchers (Steinberg, 1964; Jester, 1973) have stated that in selective catching of target species, color selection would be suitable and hence decrease the amount of undesired catch and therefore it is important for stock management. The material and the color of that material used in the making of the gill nets were reported to be effective on the catch efficiency and materials with lighter colors were especially 1.8 times more effective on the catch efficiency than the darker colored materials (Tweddle and Bodington, 1988). In this study conducted in the Keban Dam lake, the most efficient net was identified to be colored in black and this was followed by the green, blue and burgundy nets and a statistically meaningful $(\mathrm{p}<0.05)$ relation was observed between the fish species caught and the color of the net that has been used to catch that fish. These findings were in accordance with the other studies that were stated above
(Tweddle and Bodington, 1988). However, Balik and Cubuk (2001) have investigated the catch selectivity of 8 different gill nets (red, black, white, blue, light green, khaki, yellow and brown) and the color of the most efficient nets in terms of the total amount of fish caught in descending order was red, black, white, light green, yellow, blue, khaki and brown but they have found that this relation was insignificant $(\mathrm{p}>0.05)$. These findings are not in accordance with the data from the thesis study.

It is however, possible to explain this discrepancy to be due to the differences in the research locations and the species of the caught fish. In a study in Egridir lake on Stizostedion lucioperca and Carassius gibelio (Balik and Cubuk, 2006), the most efficient net for Stizostedion lucioperca was reported as the white net and for Carassius gibelio it was the dark green net. In this study conducted in the Keban Dam lake Cemisgezek region, burgundy nets for Cyprinus carpio, blue nets for Barbus esocinus and Barbus xanthopterus, black nets for Capoeta trutta and green nets for Barbus rajanorum mystaceus were determined to be efficient. Both studies are in accordance with each other in the sense that the fishing efficiency of the caught fish species differ with colored nets in various colors.

Nomura (1978) has reported that the most suitable hanging ratios for gill nets were ranging between 0.30 and 0.50 . In the study, the most suitable hanging ratio was found as 0.50 in terms of the amount of fish that has been caught. This is in accordance with the results obtained by Nomura (1978).

Backiel and Welcomme (1980) have previously stated that the gill nets with 0.50 hanging ratio was more effective than the gill nets with 0.67 hanging ratio. The study also states that 0.50 hanging ratio was more effective than 0.67 , thus in compliance with the study conducted by Backiel and Welcomme (1980). Karslen and Bjarnason (1986) have reported the most suitable hanging ratios to range between 0.50 and 0.80 . The study also states that the most suitable hanging ratio was 0.5 hence in compliance with the study was conducted. Machiels et al. (1994) have identified the nets with 0.50 hanging ratio to be more efficient than the nets with 0.25 hanging ratio in a study on Stizostedion lucioperca and Abramis brama. In the study on Cyprinus carpio, Barbus esocinus, Barbus xanthopterus, Capoeta trutta and Barbus rajanorum mystaceus, the 0.50 hanging ratio was found to be more efficient than 0.67 . The structure of the mesh is directly related to the hanging ratio. Because the shape of the ideal mesh may differ for different species and for even different populations of the same species inhabited at different geographical locations and since the 
probability of fish being caught in the net increases as the hanging ratio decreases, these two studies display similar characteristics in their findings.

In the research using gill nets with 0.5 or 0.67 hanging ratio and $40 \mathrm{~mm}$ mesh size, the statistical comparison of the number of fish caught in green, black and burgundy nets did not yield a statistically significant relation ( $p>0.05$ ) whereas the relation was significant for the blue nets $(\mathrm{p}<0.05)$. Balik and Cubuk have concluded that the difference in the amount of fish caught in gill nets with $0.33,0.40,0.50,0.60$ and 0.67 hanging ratios were statistically insignificant $(\mathrm{p}>0.05)$. In that aspect, this study of Balik and Cubuk is in accordance with their thesis study where burgundy, black and green nets with $40 \mathrm{~mm}$ mesh size were used. In this study conducted in Keban Dam lake, the investigation of the number of seasonally caught fish led to the conclusion that spring is the season with the highest catch efficiency and winter is the season with the lowest catch efficiency.

Balik and Cubuk (2001) have deduced the most efficient season to be fall and the least efficient season to be winter in the studies conducted in Beysehir lake. It is possible to link this difference to several lake specific characteristics such as the condition of the fish, the nutritional capacity of the habitat, the depth of the lake and the water temperature.

\section{CONCLUSION}

In many countries in the world, gill nets of various sizes are widely used both in seas and in inner waters. The efficiencies of these nets can only be evaluated based on the fish species in that region. Despite having broad inner water regions, the country draws attention with its inadequate production. Before all else, it is imperative to encourage the replacement of the nets with low efficiencies with highly efficient nets that would not endanger the structure of the population.

\section{REFERENCES}

Acosta, A.R. and R.S. Appeldoorn, 1995. Catching efficiency and selectivity of gillnets and trammel nets in coral reefs from Southwestern Puerto Rico. Fish. Res., 22: 175-196.

Alverson, D.L., H.M. Freeberg and J.G. Pope, 1994. A global assessment of fisheries bycatch and discards. FAO Fisheries Technical Paper No. 339. http://www.fao.org/docrep/003/t4890e/T4890E00.H TM.
Antony, P.D., 1981. Visual constrat thresold in the cod Godus morhua L. J. Fish. Biol., 19: 87-103.

Backiel, T. and R.C. Welcomme, 1980. Guide lines for sampling fish in inland waters. ELFAC Tecnical Paper No. 33, pp: 53.

Balik, L. and H. Cubuk, 2001. Effect of net colours on efficiency of monofilament gillnets for catching some fish species in lake beyksehir. Turk. J. Fish. Aquat. Sci., 1: 29-32.

Cui, G., C.S. Wardle, C.W. Glass, A.D.F. Johnstone and W.R. Mojsiewicz, 1991. Light level thresholds for visual reaction of mackerel, Scomber scombrus L., to coloured monofilament nylon gillnet materials. Fish. Res., 10: 255-263.

Dickson, W., 1989. Cod gillnet effectiveness related to local abundance, availability and fish movement. Fish. Res., 7: 127-148.

Engas, A. and S. Lokkeborg, 1994. Abundance Estimation Using Gillnet and Longline. In: The Role of Fish Behaviour Marine Fish Behaviour in Capture and Abundance Estimation, Ferno, A. and S. Olsen (Eds.). Chapter 8, Fishing New Books, London, pp: 130-163.

Hamley, J.M., 1975. Review of gillnet selectivity. J. Fish. Res. Board Can., 32: 1943-1969.

Hamley, J.M., 1980. Sampling with gillnets. FAO Guidelines for Sampling Fish in Inland Waters, EIFAC Technical Paper No. 33, pp: 37-55.

Holst, R., D. Wileman and N. Madsen, 2002. The effect of twine thickness on the size selectivity and fishing power of Baltic cod gill nets. Fish. Res., 56: 303-312.

Jester, D.B., 1973. Variations in catchability of fishes with color of gillnets. Trans. Am. Fish. Soc., 102: 109-115.

Karslen, L. and B.A. Bjarnason, 1986. Small-scale fishing with drifnets. FAO Fisheries Technicals Paper, No. 284, pp: 64.

Kurkilathi, M. and M. Rask, 1996. A comparative study of the usefulness and cathability of multimesh gill nets series in sampling of perch (Perca fluviatilis L.) and roach (Rutilis rutilis L.). Fish. Res., 27: 243-260.

Laevastu, T. and F. Favorite, 1988. Fishing and Stock Fluctuations. Fishing News, England, ISBN-13: 9780852381557, pp: 239.

Lagler, K.F., 1978. Capture, Sampling and Examination of Fishes. In: Methods for Assessment of Fish Production in Fresh Waters: IBP Handbook 3, Bagenal, B. (Ed.). 3rd Edn., Blackwell Scientific, Oxford, pp: 7-47.

Machiels, M.A.M., M. Klinge, R. Lanters and W.L.T. van Densen, 1994. Effect of snood length and hanging ratio on efficiency and selectivity of bottom-set gillnets for pikeperch, Stizostedion lucioperca L. and bream, Abramis brama. Fish. Res., 19: 231-239. 
Millner, R.S., 1985. The Use of Anchored Gill and Tangle Nets in the Sea Fisheries of England and Wales. Laboratory Leaflet, Lowesoft, pp: 27.

Narayanappa, G., A.A. Khan and R.M. Naidu, 1977. Coloured gill nets for reservoir fishing. Fish Technol. Soc., 14: 44-48.

Nomura, M., 1978. Outline of Fishing Gear and Method. Kanagawa International Fisheries Training Centre, Japan.

Pawson, M.G., 1991. The Relationship Between Catch, Effort and Stock Size in Put-and-Take Trout Fisheries, its Variability and Application to Management. In: Catch Effort Sampling Strategies: Their Application in Freshwater Fisheries Management, Cowx, I.G. (Ed.). Fishing News Books, Oxford, pp: $72-80$.

Prouzed, P. and J. Dumas, 1988. Measurement of Atlantic Salmon Spawning Escapement. In: Atlantic Salmon: Planning for the Future, Mills, D. and D. Piggins (Eds.). Croom Helm, London, pp: 325-343.
Ricker, W.E., 1975. Computation and interpretation of biological statistics of fish populations. Bull. Fish. Res. Board Can., 191: 1-382.

Steinberg, R. and H. Bohl, 1985. Experimental fishing with gill net in The Southern Nort Sea. Inf. Fischwirtsch, 32: $132-134$.

Steinberg, R., 1964. Monofilament Gill Nets in Freshwater Experiments and Practice. In: Modern Fishing Gear of the World 2, FAO (Ed.). Fishing News Books Ltd., London, pp: 111-115.

Trunen, T., 1996. The effect of twine thickness on the catchability and selectivity of gillnets for pikeperch (Sitizostedion lucioperca). Ann. Zool. Fennici., 33: 621-625.

Tweddle, D. and P. Bodington, 1988. A comparison of the effectiveness of black and white gillnets in Lake Malawi, Africa. Fish. Res., 6: 257-269.

Wardle, C.S., G. Cui, W.R. Mojsiewicz and C.W. Glass, 1991. The effect of colour on the appearance of monofilament nylon under water. Fish. Res., 10: $243-253$. 